\title{
PERPPU NOMOR 1 TAHUN 2017 TENTANG "AKSES INFORMASI KEUANGAN UNTUK KEPENTINGAN PERPAJAKAN" DAN IMPLIKASINYA TERHADAP LEMBAGA KEUANGAN DI INDONESIA
}

\begin{abstract}
Kusworini *
ABSTRACT

Access of tax officers to the financial industry customers is set forth in Perppu No. 1 2017Th, the issuance of this rule is closely linked to the financial information exchange agreement between the Automatic Exchange of Financial Ac- count Informce (AEoFIA) organized by Member States of the Organization for Economic Co-operation and Development (OECD), including Indonesia. At the same time the Perppu is at the same time the capital of the tax authorities to pursue the tax target. The tax authorities are authorized to request additional information and evidence from financial institutions, as the latter annuls several articles which have been the secret locking of financial industry customers. This Perppu will raise tax revenues given the low acceptance of the current tax base. Nevertheless this Perppu would be perfect if it could be metamorphosed into Law.
\end{abstract}

Keywords : Financial Information Access, Tax, Financial Institutions

\section{PENDAHULUAN}

Pemerintah baru saja menerbitkan Peraturan Pemerintah Pengganti UndangUndang Nomor 1 Tahun 2017 tentang "Akses Informasi Keuangan Untuk Kepentingan Perpajakan", Perppu ini bagi sebagian orang akan dianggap sangat merugikan, sebagian lagi dapat memaklumi karena sudah diwacanakan. Namun demikian lahirnya Perppu ini seperti sebuah revolusi yang hadir begitu cepat, tiba-tiba dan belum bisa diduga, apa yang akan terjadi. Apa maksud atas konteks, isi Perppu, serta langkah strategis yang harus diambil DPR dan Pemerintah.

Ide keterbukaan informasi keuangan untuk kepentingan perpajakan telah diwacanaakan beberapa tahun silam, akan tetapi masyarakat tidak pernah siap karena telah berada di zona nyaman yang amat nikmat. Rezim kerahasiaan (secrecy)

\footnotetext{
* Kusworini, Dosen Fakultas Hukum UNTAG Semarang dapat dihubungi melalui email kusworini17@gmail.com
}

telah bertahun-tahun mewarnai kehidupan masyarakat yang berlindung dibalik klaim penghormatan hak milik pribadi (privacy). Berbagai alasan diantaranya ketidak-siapan regulasi dan infrastruktur, mentalitas aparatur negara yang rawan penyimpangan, pelarian uang keluar negari, mengurangi daya saing investasi.

Data amnesti pajak menginformasi kan kemendesakan di terbitkannya Perppu ini karena, tidak kurang dari Rp. 2.900. Triliyun aset keuangan di deklarasikan selama program berlangsung yang mencapai 56 persen dari total deklarasi harta, dan Rp.2.100 triliyun diantaranya ditempatkan di dalam negeri. Hal ini berarti menginformasikan stagnasi rasio pajak dan rendahnya pencapaian terget penerimaan pajak, karena keterbatasan akses Dirjen Pajak ke data/informasi keuangan, untuk menangkal praktek penghindaran pajak dengan mengengejar data/informasi harta di luar negeri yang di depan mata saja tak terjangkau. 
Hingga saat ini Undang-Undang ketentuan umum dan tata cara perpajakan (KUP) mengatur akses data melalui permintaan (by request) hanya mencakup tujuan pemerikasaan, penyidikan dan penagihan pajak. Ketiadaan data awal yang akurat membuat pemeriksaan pajak tidak efektif dan menimbulkan sengketa yang menyulitkan. Efektivitas pemungutan pajak harus ditopang strategi memadukan identitas dengan aktivitas.

Indonesia bersama ratusan negara di dunia sepakat berpartisipasi dalam inisiatif global, tunduk pada standart yang telah ditetapkan agar sepenuhnya masuk kategori patuh, dengan cara meniadakan aturan kerahasiaan untuk kepentingan perpajakan, oleh karena itu Pemerintah perlu mengeluarkan Perppu agar pada Tanggal 30 Juni 2017 Indonesia tidak dianggap cidera janji/di cap tidak kooperatif oleh masyarakat Global, Perppu ini memenuhi persyaratan menghadapi tuntutan komitmen di tingkat global dan kebutuhan penerimaan pajak untuk pembangunan. Perppu ini pada pokoknya mengatur tentang:

1. Kewenangan dirjen pajak mendapat kan akses untuk menerima dan memperoleh informasi keuangan dalam rangka pelaksanaan ketentuan peraturan perundang-undangan di bidang perpajakan (kebutuhan domestic) dan pelaksanaan perjanjian internasional di bidang perpajakan;

2. Lembaga jasa keuangan meliputi perbankan, pasar modal, per asuransian, lembaga jasa keuangan/ entitas lain yang di kategorikan lembaga keuangan melalui Otoritas Jasa Keuangan(OJK) secara berkala wajib menyampaikan laporan berisi identitas pemegang rekening keuangan, nomor rekening keuangan, identitas lembaga jasa keuangan, saldo atau nilai rekening keuangan, penghasilan yang terkait dengan rekening keuangan;

3. Perlindungan hukum bagi pejabat maupun para pihak yang melaksanakan kewajiban dan sanksi bagi lembaga jasa keuangan dan para hak yang tidak memenuhi kewajiban;

4. Pencabutan pasal-pasal kerahasiaan di Undang-Undang ketentan umum dan tata cara perpajakan (KUP) UndangUndang Perbankan, Undang-Undang Pasar Modal, Undang-Undang Perdagangan Berjangka Komoditi dan Undang-Undang Perbankan Syariah.

Dalam penerbitan Perppu ini baru mengatur hal-hal yang bersifat normative, khususnya kewenangan akses Ditjen Pajak terhadap informasi/data keuangan melalui peniadaan pasal-pasal kerahasian UndangUndang ketentuan umum dan tata cara perpajakan (KUP) Undang-Undang Perbankan, Undang-Undang Pasar Modal, Undang-Undang Perdagangan Berjangka Komoditi dan Undang-Undang Perbankan Syariah. Dari uraian tersebu diatas maka dalam makalah ini dirumuskan suatu permasalah: Bagaimana Eksistensi Perppu Nomor 1 Tahun 2017 Dan Implikasinya Terhadap Lembaga Keuangan di Indonesia.

\section{Pembahasan}

\section{Kewenangan membuat suatu Peraturan Perundang-Undangan}

Hukum adalah norma untuk mengontrol pola tingkah laku masyarakat (het recht is om het gedrag van mens te sturen) sehingga menuju pada tatanan situasi yang damai dan sejahtera. Pada tataran filsafat hukum merupakan bentuk dari cita hukum sebagaimana dikonsepkan oleh Gustav Radbruch. bahwa cita hukum tidak lain daripada keadilan. Kemudia ia menyatakan "Est autem jus a justitia, sicut a matre sua ergo prius fuit justitia quam jus" artinya "akan tetapi hukum berasal dari keadilan seperti lahir dari kandungan 
ibunya; oleh karena itu, keadilan telah ada sebelum adanya hukum." Seperti yang dimaksud dengan keadilan. Menurut Ulpianus, keadilan adalah justitia est perpetua et contains voluntas jus suum cuique tribuendi, terjemahan bebasnya keadilan adalah suatu keinginan yang terusmenerus dan tetap untuk memberikan kepada orang apa yang menjadi haknya. ${ }^{2}$

Tujuan hukum adalah mewujudkan keadilan sehingga tercipta damai dan sejahtera, melainkan kesemprawutan dalam wajah hukum kita. Sebuah formulasi lagi Ulpianus yang mengekspresikan gagasan tetang keadilan "the precepts of right and law are these: to live honorably, not to injure another, to give to every one his own.",

Kekosongan suatu norma hukum karena tiadanya undang-undang dalam keadaan memaksa Eksekutif dapat membentuk Peraturan Pemerintah Pengganti Undang-Undang (Perppu). Dari kaca mata konstitusi berdasar Pasal 5 ayat (1) UUD 1945.

Kewenangan membuat Perppu ada di tangan eksekutif yaitu Presiden sebagai kepala Pemerintahan menurut Jimly Asshiddiqie, Presiden akan menetapkan suatu Perppu karena belum ada undangundang. Dalam bahasa Asshiddiqie, Perppu merupakan bentuk delegated legislation atau kewenangan yang didelegasikan oleh principal legislator atau pembentuk undang-undang kepada Presiden untuk menjalankan undang-undang yang bersangkutan. ${ }^{4}$

1 Peter Mahmud Marzuki, Pengantar Ilmu Hukum, Jakarta : Kencana Prenada Media Group, 2012, hal. 121.

2. Ibid.

3 Roscoe Pound, The Ideal Element In Law, Indianapolis : Libery Fund, 2002, hal. 160 Terjemahan bebasnya: "ajaran tetang hak dan hukum adalah untuk hidup saling menghormati, tidak untuk menyakiti orang lain, untuk memberikan setiap orang hak miliknya.

4 Jimly Asshiddiqie, Pengantar Hukum Tata Negara, Jakarta : Rajawali Press, 2010, hal. 173.
Sementara, Maria Farida Indrati S, dalam istilah lain yaitu delegasi kewenangan dalam pembentukan Peraturan Perundang - undangan (delegatie van wetsgevingsbevoegheid) ialah pelimpahan kewenangan membentuk peraturan perundang-undangan yang lebih tinggi kepada peraturan perundang - undangan yang lebih rendah, baik pelimpahan dinyatakan dengan tegas maupun tidak. ${ }^{5}$

Pengertian Perppu dapat ditemukan dalam Pasal 1 angka 5 Undang-Undang No. 12 Tahun 2011 tentang Pembentukan Peraturan Perundang-undangan (selanjut nya disebut UUP3) yaitu "Peraturan Perundang-undangan yang ditetapkan oleh Presiden untuk menjalankan sebagaimana mestinya."

Terdapat beberapa asas yang diatur dalam Pasal 5 UUP3 yang menjadi ramburambu yang harus dipatuhi untuk menjadikan Peraturan Perundangundangan yang baik, meliputi:

1. Kejelasan tujuan;

2. Kelembagaaan atau pejabat pembentuk yang tepat;

3. Kesesuaian antara jenis, hierarki, dan materi muatan;

4. Dapat dilaksanakan;

5. Kedayagunaan dan kehasilgunaan;

6. Kejelasan rumusan; dan

7. Keterbukaan.

Serta mengandung materi muatan (material contents) sebagaimana telah digariskan dalam Pasal 6 UUP3 diantara nya: a) pengayoman; b) kemanusian; c) kebangsaan; d) kekeluargaan; e) kenusantaraan; f) bhineka tunggal ika; g) keadilan; h) kesamaan kedudukan dalam hukum dan pemerintahan; i) ketertiban dan kepastian hukum; dan / atau j) keseimbang an, keserasian, dan keselarasan. Selain itu, Peraturan Perundang-undangan tertentu dapat berisi asas lain sesuai dengan bidang hukum Peraturan Perundang-undangan

5 Maria Farida Indrati S, Ilmu Perundangundangan Jenis, Fungsi, dan Materi Muatan, Yogyakarta: Kanisius, 2013, hal. 56. 
yang bersangkutan.

\section{Implikasi Perppu No 1 Tahun 2017 Terhadap Lembaga Keuangan Di Indonesia}

Kedudukan Perppu sejajar dengan undang-undang karena hakekatnya Perppu adalah peraturan pengganti undang-undang sebagaimana dikemukakan oleh Jimly Asshiddiqie dan Maria Farida Indriati S. Secara jelasnya, jenis dan hierarki dimuat dalam Pasal 7 ayat (1) UUP3, meliputi:

a. Undang-Undang Dasar Negara Republik Indonesia Tahun 1945;

b. Ketetapan Majelis Permusyawaratan Rakyat;

c, Undang-Undang/Peraturan Pemerintah Pengganti Undang-Undang;

d. Peraturan Pemerintah;

e. Peraturan Presiden;

f. Peraturan Daerah Provinsi; dan

g. Peraturan Daerah Kabupaten/Kota.

Peraturan Pemerintah Pengganti Undang-Undang atau Perppu Nomor 1 Tahun 2017 tentang Akses Informasi Keuangan Untuk Kepentingan Perpajakan, memberikan otoritas pajak untuk menyidik dan meneliti data keuangan nasabah. Otoritas pajak berwenang meminta informasi dan bukti tambahan dari lembaga keuangan. Sebab Perppu ini menganuir baberapa pasal yang selama ini menjadi kerahasiaan nasabah induetri financial.

Jika dilihat pasal pasal tentang Akses Informasi Keuangan Untuk Kepentingan Perpajakan, pasal pasal yang tekait antara lain :

\section{Pasal 2}

1 Direktur Jenderal Pajak berwenang mendapatkan akses informasi keuang an untuk kepentingan perpajakan sebagaimana dimaksud dalam Pasal 1 dari lembaga jasa keuangan yang melaksanakan kegiatan di sektor perbankan, pasar modal, perasuransian, lembaga jasa keuangan lainnya, dan/atau entitas lain yang dikategorikan sebagai lembaga keuangan sesuai standar pertukaran informasi keuangan berdasarkan perjanjian internasional di bidang perpajakan.

2 Lembaga jasa keuangan, lembaga jasa keuangan lainnya, dan/atau entitas lain sebagaimana dimaksud pada ayat (1) wajib menyampaikan kepada Direktur Jenderal Pajak:

a. Laporan yang berisi informasi keuangan sesuai standar pertukaran informasi keuangan berdasarkan perjanjian internasional di bidang perpajakan untuk setiap rekening keuangan yang diidentifikasikan sebagai rekening keuangan yang wajib dilaporkan; dan

b. Laporan yang berisi informasi keuangan untuk kepentingan perpajakan, yang dikelola oleh lembaga jasa keuangan, lembaga jasa keuangan lainnya, dan/atau entitas lain dimaksud selama satu tahun kalender.

3. Laporan yang berisi informasi keuang an sebagaimana dimaksud pada ayat (2) paling sedikit memuat:

a. Identitas pemegang rekening keuangan;

b. Nomor rekening keuangan;

c. Identitas lembaga jasa keuangan;

d. Saldo atau nilai rekening keuangan; dan

e. Penghasilan yang terkait dengan rekening keuangan.

4. Dalam rangka penyampaian laporan sebagaimana dimaksud pada ayat (2) huruf a, lembaga jasa keuangan, lembaga jasa keuangan lainnya, dan/ atau entitas lain sebagaimana dimaksud pada ayat (1) wajib melakukan prosedur identifikasi rekening keuang an sesuai standar pertukaran informasi keuangan berdasarkan perjanjian internasional di bidang perpajakan.

5. Prosedur identifikasi rekening keuang 
an sebagaimana dimaksud pada ayat (4) paling sedikit meliputi kegiatan:

a. Melakukan verifikasi untuk menentukan negara domisili untuk kepentingan perpajakan bagi pemegang rekening keuangan, baik orang pribadi maupun entitas;

b. Melakukan verifikasi untuk menentukan pemegang rekening keuangan sebagaimana dimaksud dalam huruf a merupakan pemegang rekening keuangan yang wajib dilaporkan;

c. Melakukan verifikasi untuk menentukan rekening keuangan yang dimiliki oleh pemegang rekening keuangan sebagaimana dimaksud dalam huruf a merupakan rekening keuangan yang wajib dilaporkan;

d. Melakukan verifikasi terhadap entitas pemegang rekening keuang an untuk menentukan pengendali entitas dimaksud merupakan orang pribadi yang wajib dilaporkan; dan

e. Melakukan dokumentasi atas kegiatan yang dilakukan dalam rangka prosedur identifikasi rekening keuangan, termasuk menyimpan dokumen yang diperoleh atau digunakan.

6. Lembaga jasa keuangan, lembaga jasa keuangan lainnya, dan/atau entitas lain sebagaimana dimaksud pada ayat (1), tidak diperbolehkan melayani:

a. Pembukaan rekening keuangan baru bagi nasabah baru; atau

b. Transaksi baru terkait rekening keuangan bagi nasabah lama, yang menolak untuk mematuhi ketentuan identifikasi rekening keuangan sebagaimana dimaksud pada ayat (4).

7. Dalam hal diminta oleh Direktur Jenderal Pajak, lembaga jasa keuangan, lembaga jasa keuangan lainnya, dan/atau entitas lain sebagaimana dimaksud pada ayat (1) yang memperoleh atau menyelenggarakan dokumentasi dalam bahasa lain selain Bahasa Indonesia, harus memberikan terjemahan dokumentasi dimaksud ke dalam Bahasa Indonesia.

8. Dalam hal lembaga jasa keuangan, lembaga jasa keuangan lainnya, dan/atau entitas lain sebagaimana dimaksud pada ayat (1) terikat oleh kewajiban merahasiakan berdasarkan ketentuan peraturan perundangundangan, kewajiban merahasiakan tersebut tidak berlaku dalam melaksanakan Peraturan Pemerintah Pengganti Undang-Undang ini.

\section{Pasal 3}

1. Kewajiban penyampaian laporan sebagaimana dimaksud dalam Pasal 2 ayat (2) dilakukan dengan:

a. Mekanisme elektronik melalui Otoritas Jasa Keuangan bagi lembaga jasa keuangan sebagai mana dimaksud dalam Pasal 2 ayat (1), untuk laporan sebagaimana dimaksud dalam Pasal 2 ayat (2) hurufa;

b. Mekanisme non - elektronik sepanjang mekanisme elektronik belum tersedia, kepada Direktur Jenderal Pajak, bagi lembaga jasa keuangan lainnya dan entitas lain sebagaimana dimaksud dalam Pasal 2 ayat (1), untuk laporan sebagai mana dimaksud dalam Pasal 2 ayat (2) hurufa; dan

c. Mekanisme non-elektronik sepanjang mekanisme elektronik belum tersedia, kepada Direktur Jenderal Pajak, untuk laporan sebagaimana dimaksud dalam Pasal 2 ayat (2) hurufb.

2. Dalam hal terdapat perubahan mekanisme sebagaimana dimaksud pada ayat (1), Menteri Keuangan dapat menentukan mekanisme lain setelah mendapat pertimbangan Ketua Dewan 
Komisioner Otoritas Jasa Keuangan.

3. Terhadap penyampaian laporan melalui mekanisme sebagaimana dimaksud pada ayat (1) huruf a, berlaku ketentuan sebagai berikut:

a. Lembaga jasa keuangan sebagai mana dimaksud dalam Pasal 2 ayat (1) wajib menyampaikan kepada Otoritas Jasa Keuangan paling lama 60 (enam puluh) hari sebelum batas waktu berakhirnya periode pertukaran informasi keuangan antara Indonesia dengan negara atau yurisdiksi lain berdasarkan perjanjian internasional di bidang perpajakan; dan

b. Otoritas Jasa Keuangan menyampai kan kepada Direktorat Jenderal Pajak paling lama 30 (tiga puluh) hari sebelum batas waktu berakhirnya periode pertukaran informasi keuangan antara Indonesia dengan negara atau yurisdiksi lain berdasarkan perjanjian internasional di bidang perpajakan.

4. Penyampaian laporan melalui mekanisme sebagaimana dimaksud pada ayat (1) huruf $b$ dan huruf $c$ dilakukan oleh lembaga jasa keuangan, lembaga jasa keuangan lainnya, dan/atau entitas lain sebagaimana dimaksud dalam Pasal 2 ayat (1) kepada Direktur Jenderal Pajak paling lama 4 (empat) bulan setelah akhir tahun kalender.

\section{Pasal 4}

1. Selain menerima laporan sebagaimana dimaksud dalam Pasal 2 ayat (2), Direktur Jenderal Pajak berwenang untuk meminta informasi dan/atau bukti atau keterangan dari lembaga jasa keuangan, lembaga jasa keuangan lainnya, dan/atau entitas lain.

2. Lembaga jasa keuangan, lembaga jasa keuangan lainnya, dan/atau entitas lain wajib memberikan informasi dan/atau bukti atau keterangan sebagaimana dimaksud pada ayat (1) kepada Direktur Jenderal Pajak.

3. Informasi keuangan yang tercantum dalam laporan sebagaimana dimaksud dalam Pasal 2 ayat (2) dan informasi dan/atau bukti atau keterangan sebagaimana dimaksud pada ayat (1) digunakan sebagai basis data perpajakan Direktorat Jenderal Pajak.

\section{Pasal 5}

Berdasarkan perjanjian internasional di bidang perpajakan, Menteri Keuangan berwenang melaksanakan pertukaran informasi keuangan sebagaimana dimaksud dalam Pasal 2 ayat (2) dan / atau informasi dan/atau bukti atau keterangan sebagaimana dimaksud dalam Pasal 4 ayat (1) dengan otoritas yang berwenang di negara atau yurisdiksi lain.

\section{Pasal 6}

1. Menteri Keuangan dan / atau pegawai Kementerian Keuangan dalam melaksanakan tugas yang berkaitan dengan pelaksanaan akses dan pertukaran informasi keuangan untuk kepentingan perpajakan, tidak dapat dituntut secara pidana maupun digugat secara perdata.

2. Pimpinan dan/atau pegawai Otoritas Jasa Keuangan yang memenuhi kewajiban penyampaian laporan sebagaimana dimaksud dalam Pasal 3 ayat (1) huruf a, tidak dapat dituntut secara pidana dan/atau digugat secara perdata.

3. Pimpinan dan/atau pegawai lembaga jasa keuangan, pimpinan dan/atau pegawai lembaga jasa keuangan lainnya, dan pimpinan dan/atau pegawai entitas lain sebagaimana dimaksud dalam Pasal 2 ayat (1) yang memenuhi kewajiban penyampaian 
laporan sebagaimanadimaksud dalam Pasal 2 ayat (2), dan/atau pemberian informasi dan/atau bukti atau keterangan sebagaimana dimaksud dalam Pasal 4 ayat (2), tidak dapat dituntut secara pidana dan/atau digugat secara perdata.

\section{Pasal 6}

1. Pimpinan dan/atau pegawai lembaga jasa keuangan, pimpinan dan/atau pegawai lembaga jasa keuangan lainnya, dan pimpinan dan/atau pegawai entitas lain sebagaimana dimaksud dalam Pasal 2 ayat (1), yang:

a. Tidak menyampaikan laporan sebagaimana dimaksud dalam Pasal 2 ayat (2);

b. Tidak melaksanakan prosedur identifikasi rekening keuangan secara benar sebagaimana dimaksud dalam Pasal 2 ayat (4); dan/atau

c. Tidak memberikan informasi dan/ atau bukti atau keterangan sebagai mana dimaksud dalam Pasal 4 ayat (2), dipidana dengan pidana kurungan paling lama 1 (satu) tahun atau denda paling banyak Rp1.000.000.000,00 (satu miliar rupiah).

2. Lembaga jasa keuangan, lembaga jasa keuangan lainnya, dan entitas lain sebagaimana dimaksud dalam Pasal 2 ayat (1), yang:

a. Tidak menyampaikan laporan sebagaimana dimaksud dalam Pasal 2 ayat (2);

b. Tidak melaksanakan prosedur identifikasi rekening keuangan secara benar sebagaimana dimaksud dalam Pasal 2 ayat (4); dan/atau

c. tidak memberikan informasi dan/atau bukti atau keterangan sebagaimana dimaksud dalam Pasal 4 ayat (2), dipidana denda paling banyak Rp1.000.000.000,00 (satu miliar rupiah).

3. Setiap orang yang membuat pernyataan palsu atau menyembunyikan atau mengurangkan informasi yang sebenarnya dari informasi yang wajib disampaikan dalam laporan sebagai mana dimaksud dalam Pasal 2 ayat (2), dipidana dengan pidana kurungan paling lama 1 (satu) tahun atau denda paling banyak Rp1.000.000.000,00 (satu miliar rupiah).

Dalam penerbitan Perppu Nomor 1 Tahun 2017 ini mengeliminasi/menghapus pasal-Pasal Kerahasian dalam undangundang yang bekaitan dengan :

1. Undang-Undang tentang Ketentuan Umum Dan Tata Cara Perpajakan (KUP);

2. Undang-Undang Perbankan;

3. Undang-Undang Pasar Modal;

4. Undang-Undang Perasuransian;

5. Undang-Undang Perdagangan Ber jangka Komoditi; dan

6. Undang-Undang Perbankan Syariah.

Berikut ini pasal-pasal yang Teranulir oleh Perppu No 1 Tahun 2017 yang berkaitan dengan kerahasiaan lembaga keuangan :

1. Undang-Undang Republik Indonesia Nomor 16 Tahun 2000 Tentang Perubahan Kedua Atas UndangUndang Nomor 6 Tahun 1983 Tentang Ketentuan Umum Dan Tata Cara Perpajakan:

\section{Pasal 35}

(2) Dalam hal pihak ketiga yang bersangkutan tersebut terikat oleh kewajiban untuk merahasiakan, kewajiban untuk merahasiakan itu ditiadakan oleh permintaan untuk keperluan pemeriksaan sesuai dengan ketentuan peraturan perundangundangan yang berlaku.

2. Undang-Undang UU Nomor 10 Tahun 1998 Perubahan Atas Undang-Undang Nomor 7 Tahun 1992 Tentang Perbankan 
Pasal 40

1. Bank dilarang memberikan keterangan yang tercatat pada bank tentang keadaan keuangan dan halhal lain dari nasabahnya, yang wajib dirahasiakan oleh bank menurut kelaziman dalam dunia perbankan, kecuali dalam hal sebagaimana dimaksud dalam Pasal 41, Pasal 42, Pasal 43, dan Pasal 44.

2. Ketentuan sebagaimana dimaksud dalam ayat (1) berlaku pula bagi pihak terafiliasi. Pasal 41 (1) Untuk kepentingan perpajakan Menteri berwenang mengeluarkan perintah tertulis kepada Bank agar memberikan keterangan dan memperlihatkan buktibukti tertulis serta surat-surat mengenai keadaan keuangan nasabah tertentu kepada pejabat pajak. (2) Perintah tertulis sebagaimana dimaksud dalam ayat (1), harus menyebutkan nama pejabat pajak dan nama nasabah wajib pajak yang dikehendaki keterangannya.

3. Undang-Undang Republik Indonesia Nomor 8 Tahun 1995 Tentang Pasar Modal

\section{Pasal 47}

1. Kustodian atau Pihak terafiliasinya dilarang memberikan keterangan mengenai rekening Efek nasabah kepada Pihak mana pun, kecuali kepada:

a. Pihak yang ditunjuk secara tertulis oleh pemegang rekening atau ahli waris pemegang rekening;

b. Polisi, Jaksa, atau Hakim untuk kepentingan peradilan perkara pidana;

c. Pengadilan untuk kepentingan peradilan perkara perdata atas per mintaan Pihak-Pihak yang beperkara; d. Pejabat Pajak untuk kepentingan perpajakan;

e. Bapepam, Bursa Efek, Lembaga Kliring dan Penjaminan, Emiten, Biro Administrasi Efek, atau Kustodian lain dalam rangka melaksanakan fungsinya masingmasing; atau

f. Pihak yang memberikan jasa kepada Kustodian, termasuk konsultan, Konsultan Hukum, danAkuntan.

2. Setiap Pihak sebagaimana dimaksud dalam ayat (1) huruf a sampai dengan huruf $f$ yang memperoleh keterangan mengenai rekening Efek nasabah dari Kustodian atau afiliasinya dilarang memberikan keterangan dimaksud kepada Pihak mana pun, kecuali diperlukan dalam pelaksanaan fungsi nya masing-masing.

3. Permintaan untuk memperoleh keterangan mengenai rekening Efek nasabah sebagaimana dimaksud dalam ayat (1) huruf b, huruf $c$, dan huruf $d$ diajukan oleh Kepala Kepolisian Republik Indonesia, Jaksa Agung, Ketua Mahkamah Agung atau pejabat yang ditunjuk, dan Direktur Jenderal Pajak kepada Bapepam untuk memperoleh persetujuan dengan menyebutkan nama dan jabatan polisi, jaksa, hakim atau pejabat pajak, nama atau nomor pemegang rekening, sebabsebab keterangan diperlukan, dan alasan permintaan dimaksud.

4. Undang-Undang Nomor 40 Tahun 2014 Tentang Perasuransian

\section{Pasal 67}

Pihak lain yang ditunjuk atau ditugasi oleh Otoritas Jasa Keuangan sebagaimana dimaksud dalam Pasa.159 ayat (1) dan Pasal 61 ayat (21 dilarang menggunakan atau mengungkapkan informasi apa pun yang bersifat rahasia kepada pihak lain, kecuali dalam rangka pelaksanaan fungsi, 
tugas, dan wewenangnya berdasarkan keputusan Otoritas Jasa Keuangan atau diwajibkan oleh undang-undang.

5. Undang-Undang Republik Indonesia Nomor 10 Tahun 2011 Tentang Perubah an Atas Undang-Undang Nomor 32 Tahun 1997 Tentang Perdagangan Berjangka Komoditi

\section{Pasal 73}

Setiap Pihak yang memanfaatkan setiap informasi yang diperoleh untuk kepentingan pribadi atau mengungkap kan kepada pihak lain sebagaimana dimaksud dalam Pasal 8, dipidana dengan pidana penjara paling singkat 1 (satu) tahun dan paling lama 3 (tiga) tahun, dan/atau denda paling sedikit Rp500.000.000,00 (lima ratus juta rupiah) dan paling banyak Rp1.500.000.000,00 (satu miliar lima ratus juta rupiah). 34. Di antara Pasal 73 dan Pasal 74 disisipkan 7 (tujuh) pasal,

6. Undang-Undang Republik Indonesia Nomor 21 Tahun 2008 Tentang Perbankan Syariah

\section{Pasal 41}

Bank dan Pihak Terafiliasi wajib merahasiakan keterangan mengenai Nasabah Penyimpan dan Simpanannya serta Nasabah Investor dan Investasinya.

\section{Langkah strategis yang perlu segera diambil oleh:}

1. DPR Perlu segera memberikan dukungan pada penuntasan reformasi perpajakan dengan mengesahkan perppu mejadi undang-undang dan bersama pemerintah menyelesaikan revisi Undang Undang Ketentuan Umum Dan Tata Cara Perpajakan (KUP) dan Undang-Undang Perbankan, termasuk segera menyetujui Rencana UndangUndang Perlindungan Data Pribadi.

2. Nasabah/WP Kewenangan yang besar dan tuntutan tranparansi ini harus diimbangi dengan akuntabilitas, yaitu perlindungan data nasabah/WP dari penyalahgunaan di luar kepentingan perpajakan dan pertangung-jawaban pemanfaatan data keuangan. Keragu raguan Publik terhadap integritas aparatur Negara sangat beralasan sehingga perlu segera dibuat regulasi yang secara eksplisit mengatur perlindungan data system administrasi yang transparan dan akuntabel dalam menawasipemanfaaatan data, serta formulasi sanksi yang berat bagi pihak yang menyalahgunakan kewenagan.

3. Kementerian keuangan segera menerbitkan atauran peaksanaan yang meberikan kepastian hukum, serta bersama sama Bank Indonesia dan Otoritas Jasa Keuangan (OJK) segera melakukan sosialisasi yang massif dan menjangkau masyarakat luas agar kepercaan public dan stabilitas ekonomi dan moneter tiak terganggu. Disisi lain anturan in menjadi peluang baru bagi pemerintah untuk manari dana yang selama ini terseimpan di luar egeri atau dana di dalama negeriyang akan disalurkan di sector $\mathrm{p}$ [roduksi, maka reformasi sisstem keuangan agar lebih krdibel, akuntebel, dan kompetitif melalui perbaikan salama ensentif, kepastian hukum, penyederhanaan administrasi mutlak diperlukan.

4. Masyarakat baik sebagai nasabah maupun Wajib pajak tidak perlu kuatir berlebihan, era keterbukaan ini wajar, oleh karena itu diperlukan respon yang tepat bukan siasat untuk mempertahan kan zona nyaman kerahasiaan, melainkan ikut merawat perlindungan data pribaadi, kebijakan ini jutru meneguhkan semangat pengampunan pajak, i wajib pajak selama Sembilan bulan telah diberi kesempatan untuk melaporkan harta yang belum diungkap dan diampuni, maka kini tak ada alasan dan cara lain kecuali 
melakukan penegakan hukum yang adil.

5. Bagi para wajib pajak yang telah mengikuti program amnesty dan diikuti dengan pembetulan SKP dengan jujur mendapat insentif dan sebaliknya menjadi disinsentif atau hukuman bagi mereka yang memilih tidak jujur,

6. Direktorat Jenderal Pajak Kementerian Keuangan memiliki keleluasaan untuk:

a. Mengakses informasi keuangan nasabah yang merupakan wajib pajak. Dengan kondisi mudahnya akses informasi perbankan ke dunia internasional secara global, maka situasi tersebut dapat digunakan untuk sistem kompetitif terbuka.

b. Perppu tersebut berkaitan dengan manajemen perbankan secara siber. Karena itu Jenderal Pajak Kementerian Keuangan harus dibekali dengan batasan yang kuat agar tidak berujung penyalah gunaan oleh pihak-pihak tertentu.

c. Prinsip manajemen terbuka membuat aktivitas perbankan terbuka dan transparan. Sehingga siapa pun tidak bisa menyembunyi kannya. "Sampai berapa rupiah pun tahu semua. Jadi kita sudah enggak bisa lagi menyembunyikan. Masyarakat tidak bisa menghindari ketentuan yang ada di era transformasi kultural itu, khusus nya perbankan,"

d. Setelah adanya Perppu Akses Informasi Keuangan untuk Kepentingan Perpajakan, Ditjen Pajak tidak perlu lagi susah payah, bisa langsung meminta data kepada bank.

Dampak Pemberlakuan Perppu Akses Informasi Keuangan

Sejumlah dampak berpotensi muncul akibat kebijakan dari pemberlaku an Peraturan Pemerintah Pengganti
Undang-Undang ( $\underline{\text { Perppu }}$ ) Nomor 1 Tahun 2017 tentang Akses Informasi Keuangan untuk Kepentingan Perpajakan. Melalui aturan ini, Direktorat Jenderal Pajak Kementerian Keuangan memiliki keleluasaan untuk mengakses informasi keuangan nasabah yang merupakan wajib pajak.

1. Dampak pertama adalah konsekuensi bagi persaingan bisnis perbankan. Dengan kondisi mudahnya akses informasi perbankan ke dunia inter nasional secara global, maka situasi tersebut dapat digunakan untuk sistem kompetitif terbuka.

2. Dampak Kedua, perppu tersebut berkaitan dengan manajemen perbankan secara siber. Karena itu harus dibekali dengan batasan yang kuat agar tidak berujung penyalahgunaan oleh pihak-pihak tertentu.

3. Dampak Ketiga, prinsip manajemen terbuka tersebut membuat aktivitas perbankan terbuka dan transparan. Sehingga siapa pun tidak bisa menyembunyikannya.

Oleh karena itu, merupakan tugas pemerintah untuk memperkuat kebijakan ini dengan sistem yang mampu mencegah peretasan atau hacking.

\section{Kesimpulan}

Perppu akan dimanfaatkan untuk informasi keuangan sebagai data awal untuk keperluan profiling kepatuhan wajib Pajak. Bagi profaile yang sudah sesuai akan termasuk klasifikasi patuh dan tanpa resiko justu berhak mendapatkan layanan prima. Bagi yang belum patuh dan berisiko tinggi ini akan menjadikan petunjuk untuk pemeriksakan pajak dengan meminta pembukaan rekening ke OJK hal ini yang mempengaruhi rasa keadilan dan memberikan kelegaaan. 


\section{Daftara Pustaka}

DHM Meuwissen, Pengembangan Hukum, Pro Justitia, Universitas Parahyangan, Th. XII, No. 32, Januari 1994

J.J.H. Bruggink, Rechts Reflecties, Grondbegrippen uit de Rechtstheorie, alih bahasa Arief Sidharta, Refleksi Tentang Hukum, Citra Aditya Bakti, Bandung, 1999,

Jimly Asshiddiqie, Pengantar Hukum Tata Negara, Jakarta : Rajawali Press, 2010,

Maria Farida Indrati S, Ilmu Perundangundangan Jenis, Fungsi, dan Materi Muatan Yogyakarta: Kanisius, 2013
Mariam Datu, Badrulzaman, Aneka Hukum Bisnis, Alumni, Bandung, 1994.

Nierop, Hypotheekrech, cetakan kedua, Tjeenk Willink, Zwolle, 1937.

Ofmann, Het Nederlands Zakenrecht, J.B. Wolters, Groningen - De Haag Batavia, 1933.

Pitlo, Het Zakenrecht Naar Het Nederlands Burgelijk Weboek, Tjeenk Willink \& Zoon, Haarlem, 1949.

Peter Mahmud Marzuki, Pengantar Ilmu Hukum, Jakarta : Kencana Prenada Media Group, 2012.

Roscoe Pound, The Ideal Element In Law, Indianapolis : Libery Fund, 2002, 